Agroradix Vol. 3 No.1 Desember (2019)

ISSN : 2621-0665

\title{
PERBEDAAN KANDUNGAN VITAMIN C SELAI CEMPEDAK PADA PEMERAMAN TRADISIONAL DENGAN PEMERAMAN KARBID
}

\author{
Dwi Nur Aini Dahlan \\ Program Studi Pendidikan Islam Anak Usia Dini, Fakultas Tarbiyah dan Ilmu Keguruan, \\ IAIN Samarinda \\ Korespondensi : ai3_nii@yahoo.com
}

\begin{abstract}
ABSTRAK
Buah cempedak (Arthocarpus champeden) termasuk buah klimaterik yang merupakan salah satu jenis tanaman asli indonesia. Meski masih mentah buah klimaterik dapat dipanen dan matang setelah pemeraman. Pengolahan buah menjadi selai bertujuan untuk memperpanjang masa simpan, meningkatkan penganeka ragaman produk dan menambah nilai ekonomis. Mutu selai cempedak akan semakin baik jika memiliki kandungan vitamin salah satunya adalah vitamin C. Tujuan penelitian ini adalah mengetahui jenis pemeraman yang tepat untuk menghasilkan selai cempedak yang mengandung vitamin C. Cara kerja pemeraman dalam penelitian ini terdiri dari 3 tahapan yaitu 1. Pemeraman, 2. Pembuatan selai dan 3 uji kandungan vitamin C. Data yang diperoleh dianalisis menggunakan uji One Way Anava dengan aplikasi SPSS statistic 21. Hasil penelitian menunjukkan terdapat perbedaan yang nyata dengan taraf sig 0.26 (5\%) pada kandungan vitamin $\mathrm{C}$ selai cempedak antara cempedak yang diperam secara tradisional dengan cempedak yang diperam dengan menggunakan karbit. Hal ini dikarenakan proses pematangan buah dengan menggunakan karbit akan menjadi lebih cepat jika dibanding pematangan buah secara biasa dan juga lebih cepat mencapai stadium klimaterik.
\end{abstract}

Kata kunci : Cempedak, Vitamin C, Pemeraman Cempedak, Arthocarpus champeden

\begin{abstract}
Cempedak fruit (Arthocarpus champeden) is a climatic fruit which is one of the native Indonesian plants. Although still raw climatic fruit can be harvested and ripe after ripening. Fruit processing into jam aims to extend the shelf life, increase the type of product and add economic value. The quality of cempedak jam will be better if it contains vitamin $\mathrm{C}$. The purpose of this research was to determine the right type of ripening to produce cempedak jam which contains lots of vitamin C. How it works curing in this research consists of 3 stages including 1 . Ripening fruit, 2. Making jam and 3 testing the content of vitamin C. Data analysis obtained using the One Way Anova test with SPSS statistical applications 21 . The results showed a significant difference with a sig level of $0.26(5 \%)$ in the content of vitamin C Cempedak jam between cempedak ripening traditionally and cempedak ripening using carbide. This is because the process of fruit ripening using carbide is faster than regular fruit ripening and can also reach the climateric stage faster.
\end{abstract}

Keyword : Cempedak, Vitamin C, Cempedak Ripening, Arthocarpus champeden 
Agroradix Vol. 3 No.1 Desember (2019)

ISSN : 2621-0665

\section{PENDAHULUAN}

Buah cempedak (Arthocarpus champeden) termasuk salah satu jenis tanaman asli Indonesia (Arif dkk. 2014). Cempedak termasuk jenis tanaman buah tropik yang berbuah tahunan (fitmawati, 2018) dari famili moraceae dan memiliki nilai ekonomi tinggi (Verheij dan coronel. 1997). Saat ini cempedak mulai tersebar luas di negara thailand, semenanjung malaysia, sumatra, jawa, kalimantan, sulawesi, maluku dan papua nugini (Lim TK, 2012).

Dalam buah cempedak setiap 100 gram bagian terkandung kira-kira adalah lemak 0,4 gram, protein 3,0 gram, kalsium 20 $\mathrm{mg}$, karbohidrat 28,6 gram, fosfor $30 \mathrm{mg}$, vitamin A $200 \mathrm{SI}$, zat besi 1,5 mg, air 67,0 g, vitamin C $15 \mathrm{mg}$ serta kandungan nilai energi sebesar 116 kkal (Astawan, 2018). Buah cempedak memiliki rasa, aroma dan bentuk yang khas (Tetty, 2011). Buah cempedak termasuk dalam buah klimaterik. Panen buah klimaterik bisa dilakukan saat mentah dan proses pemeraman agar dapat matang (Leong dan shui 2002). Panen buah yang belum matang di saat proses fisiologi masih berlangsung hingga terjadinya proses pematangan buah yang disebabkan karena meningkatnya jumlah karbon dioksida dan gas etilen yang dihasilkan (Kaleka. 2013).

Pemeraman buah bisa dilakukan melalui dua teknik yaitu teknik tradisional dengan teknik modern (Sri Utami. 2013). Pemeraman tradisional bisa dilakukan dengan bantuan daun maupun ditutup rapat. Pemeraman modern yang biasa dilakukan adalah dengan menggunakan kalsium karbida. Pemasaran kalsium kabrida berbentuk bubuk dan batu berwarna abu abu kehitaman yang biasa dimanfaatkan sebagai bahan proses pengelasan dan pemacu pematangan buah (Singal dkk, 2012). 1 gram CaC menghasilkan $349 \mathrm{ml}$ asetilen yang dalam sistem pemasakan akan digunakan dengan cara mengganti etilen yang oleh buah-buahan dihasilkan secara langsung (Dahlan, 2018).

Pematangan dengan menggunakan karbid cenderung lebih cepat dibandingkan dengan bahan lainnya (Arif dkk. 2014). Selain itu, pemeraman cempedak menggunakan karbid lebih memiliki warna dan tekstur yang menarik daripada selai cempedak yang diperam secara tradisional. Pemeraman secara tradisional lebih unggul rasa dan warna selai cempedak yang dihasilkan darida yang diperam dengan menggunakan karbid (Dahlan, 2018).

Hasil pemeraman yang baik sangat menentukan kualitas buah cempedak dan olahannya. Buah cempedak menjadi buah primadona di Indonesia sehingga dijadikan berbagai makanan olahan seperti dalam pembuatan selai sebagai bahan utama. Selai diperoleh dengan cara pemasakan gula, bubur buah, dan dapat ditambahkan bahan pengental serta asam. Proporsinya adalah bagian berat gula 55\%, bagian berat buah $45 \%$, dan mempunyai minimum $65 \%$ kandungan total padatan terlarut sehingga akhirnya selai termasuk makanan yang berbentuk pasta (Anindia putri hardita, dkk. 2016).

Tujuan pengolahan selai adalah untuk peningkatan aneka ragam produk, masa simpan lebih panjang, dan bertambahnya nilai ekonomis (Andreas pandiangan, dkk. 2017). Prosedur dalam pembuatan selai merupakan proses yang rumit dengan sejumlah variabel untuk 
Agroradix Vol. 3 No.1 Desember (2019)

ISSN : 2621-0665

mengoptimalkan produk akhir (Jayanmard. 2010). Berdasarkan SII. No. 173 standard syarat mutu selai diantaranya adalah maksimum 35\% kadar air, minimum 0,5\% padatan tak terlarut, maksimum 0,7\% kadar pektin, maksimum $55 \%$ kadar gula, $50 \mathrm{mg} / \mathrm{kg}$ kadar bahan pengawet, asam asetat negatif, serat buah positif, logam berbahaya $(\mathrm{Hg}, \mathrm{Pb}$, As) negatif, bau normal, dan rasa normal. Mutu selai cempedak akan semakin baik jika memiliki kandungan vitamin.

$$
\text { Dalam membantu proses }
$$

metabolisme tubuh dan penyerapan zat gizi yang lancar diperlukan zat esensial yang berupa vitamin. Salah satu vitamin yang penting bagi tubuh ialah vitamin $\mathrm{C}^{1}$. Vitamin C merupakan senyawa kimia yang larut dalam air dan asam askorbat. Adapun vitamin $C$ mempunyai manfaat dan karakteristik yaitu larut di dalam lemak (Vitamin C ester seperti ascorbyl palmitate) atau larut di dalam air (asam askorbat-L), agar produksi kolagen meningkat, mempunyai fungsi penting dalam berfungsinya neurotransmitters, termasuk serotonin, dopamine, dan acetylcholine dan di dalam sel darah putih berakumulasi untuk tingkat respons imunitas bertahan dengan kuat (Perricone, 2007).

Berdasarkan uraian di tersebut, maka perlu dilakukan perbandingan lebih lanjut dalam melakukan pemeraman buah cempedak. Hal ini sangat menentukan kualitas selai cempedak sebelum produksi dalam jumlah besar. Dengan demikian tujuan penelitian ini adalah mengetahui jenis

\footnotetext{
${ }^{1}$ Mia Aina dan Dawam Suprayogi. UJI KUALITATIF VITAMIN C PADA BERBAGAI MAKANAN DAN PENGARUHNYA TERHADAP PEMANASAN
}

pemeraman yang tepat untuk menghasilkan selai cempedak yang mengandung vitamin c.

\section{METODE PENELITIAN}

\section{Tempat dan Waktu Penelitian}

Penelitian ini dilakukan Universitas Mulawarman Samarinda pada bulan JuniAgustus 2019.

\section{Cara kerja}

Cara kerja pemeraman buah yaitu dengan memasukkan buah kedalam kardus kemudian ditutup rapat. Untuk pemeraman karbid ebelum ditutp terlebih dahulu ditambahkan karbid.

$$
\begin{aligned}
& \text { Cara kerja pembuatan selai } \\
& \text { cempedak: } \\
& \text { Buah cempedak dikupas, dicuci }
\end{aligned}
$$
kemudian ditimbang $100 \mathrm{~g}, 10$ gula pasir g, asam sitrat $0,1 \mathrm{~g}$ ), selanjutnya daging buah cempedak diblanching dengan suhu $60-80^{\circ} \mathrm{C}$ selama 5 menit kemudian dipotong kecilkecil dan diblender halus. Setelah dihaluskan, kemudian dimasak pada wajan dan ditambahkan gula pasir. selama proses pemasakan, bubur cempedak diaduk terusmenerus hingga berubah warnanya menjadi coklat dan menjadi kental. Setelah berwarna coklat, adonan cempedak diberi asam sitrat (1 g) dan diaduk hingga merata. Setelah kental kemudian selai cempedak didinginkan dan dimasukkan ke dalam botol yang sudah disterilkan.

\section{Analisis Data}

Analisis data yang diperoleh akan menggunakan uji One Way Anava. Pengujian dibantu dengan aplikasi SPSS statistic 21. 
Agroradix Vol. 3 No.1 Desember (2019)

ISSN : 2621-0665

\section{HASIL DAN PEMBAHASAN}

Untuk melihat pengaruh pemeraman

buah cempedak terhadap kandungan
Vitamin C, maka dilakukan uji normalitas. Uji distribusi normalitas dapat dilihat pada Tabel 2.

Tabel 2. Uji distribusi normalitas kandungan vitamin c

\begin{tabular}{|c|c|c|c|c|c|c|c|}
\hline & jenis & \multicolumn{3}{|c|}{ Kolmogorov-Smirnov ${ }^{\text {a }}$} & \multicolumn{3}{|c|}{ Shapiro-Wilk } \\
\hline & & Statistic & df & Sig. & Statistic & df & Sig. \\
\hline Vitamin c & Karbit & .252 & 3 & & .965 & 3 & .639 \\
\hline & Tradisional & .201 & 3 & & .995 & 3 & .859 \\
\hline
\end{tabular}

Hasil statistika dengan menggunakan

SPSS menunjukkan bahwa nilai signifikansi jenis pemeraman dengan menggunakan karbit 0,639 sedangkan kelompok jenis pemeraman tradisional 0,859 . Hal tersebut menunjukkan bahwa nilai signifikansi lebih

besar dari 0,05 yang artinya data berdistribusi normal.

Berdasarkan hasil yang telah diperoleh maka dapat dilakukan uji homogenitas yakni untuk melihat varian data. Uji varian data dapat dilihat pada tabel 3.

Tabel 3. Uji varian data kandungan vitamin c pada selai cempedak

\begin{tabular}{|c|c|c|c|}
\hline Levene Statistic & df1 & $\mathrm{df} 2$ & Sig. \\
\hline .768 & 1 & 4 & .430 \\
\hline
\end{tabular}

Nilai signifikansi menunjukkan bahwa nilai signifikansi varian data 0,430 sehingga nilai signifikansi varian data lebih besar dari 0,05. Dapat disimpulkan bahwa varian ke dua kelompok pemeraman secara tradisional dan pemeraman dengan karbit adalah sama sehingga asumsi uji homogenitas untuk one way anava telah terpenuhi. Uji one way ANOVA dilakukan untuk melihat perbedaan jenis pemeraman pada kandungan vitamin c pada selai dengan taraf $5 \%$. Uji one way ANOVA yang dilakukan didapatkan hasil seperti pada tabel 4.

Tabel 4. Uji anava kandungan vitamin c pada selai cempedak

\begin{tabular}{|l|r|r|r|r|r|}
\hline & Sum of Squares & Df & Mean Square & F & \multicolumn{1}{c|}{ Sig. } \\
\hline Between Groups & 19.657 & 1 & 19.657 & 11.844 & .026 \\
\hline Within Groups & 6.639 & 4 & 1.660 & & \\
\hline Total & 26.295 & 5 & & & \\
\hline
\end{tabular}

Hasil analisis statisk ANAVA menunjukkan bahwa nilai signifikansi sebesar 0,026. Hal tersebut menunjukkan bahwa nilai signifikansi lebih kecil dari 0,05 yang berarti Ho ditolak. Uji statistik tersebut berarti menunjukkan terdapat perbedaan 
Agroradix Vol. 3 No.1 Desember (2019)

ISSN : 2621-0665

yang nyata pada kandungan vitamin c selai

diperam dengan menggunakan karbit. Ratacempedak antara cempedak yang diperam rata kandungan vitamin $\mathrm{c}$ pada selai secara tradisional dengan cempedak yang cempedak dapat dilihat pada gambar 1 .

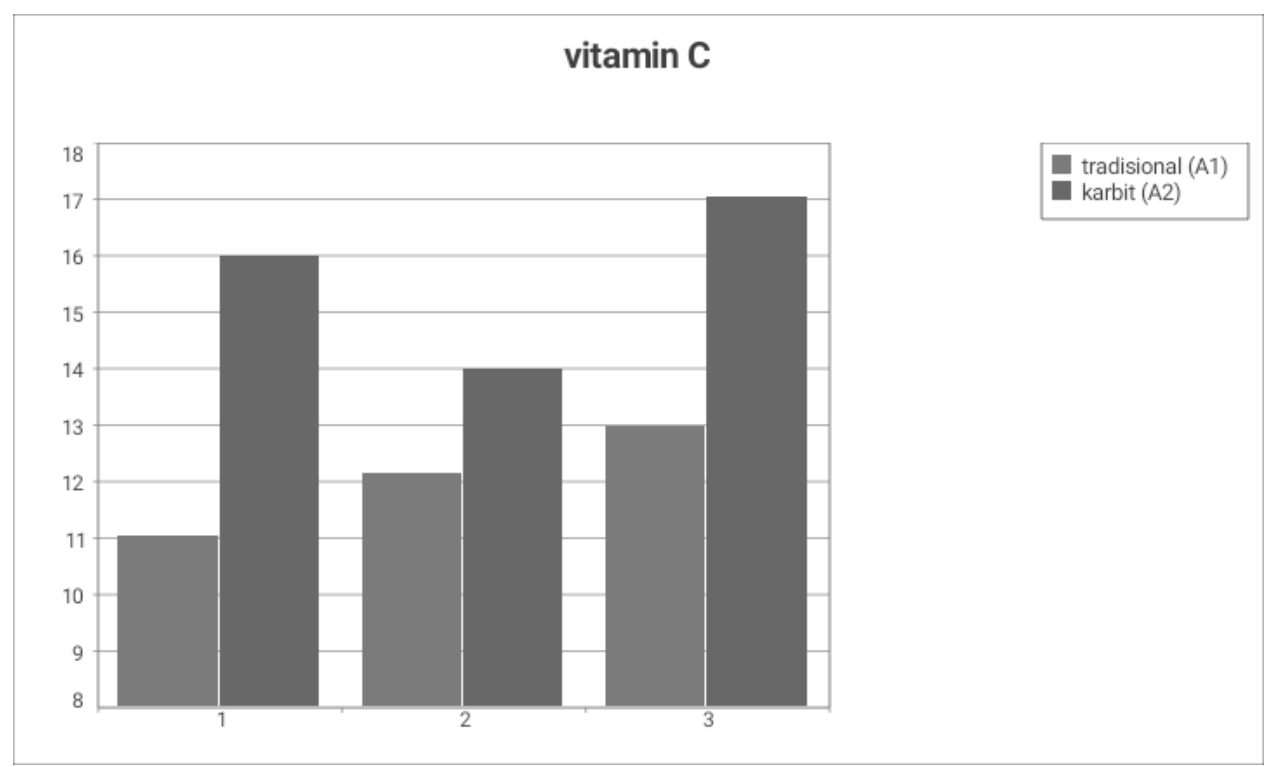

Gambar 1. nilai rata-rata setiap ulangan pada kandungan vitamin c

Gambar tersebut menunjukkan bahwa selai cempedak yang cempedaknya diperam dengan menggunakan karbit didapatkan nilai ulangan 1: 16.02 ulangan II: 14.01 dan ulangan III: 17.05. Nilai total dari keseluruhan vitamin $\mathrm{c}$ dari seluruh ulangan adalah 47.08 dengan nilai rata-rata 15.67 $\mathrm{mg} / 100 \mathrm{mg}$. Selai cempedak yang cempedaknya diperam secara tradisional didapatkan nilai ulangan 1: 11.05 ulangan II: 12.15 dan ulangan III: 13. Nilai total dari keseluruhan vitamin $\mathrm{c}$ dari seluruh ulangan adalah 36.2 dengan nilai ratarata 12.07 $\mathrm{mg} / 100 \mathrm{mg}$. Dengan demikian nilai kandungan vitamin c pada selai cempedak secara rata-rata lebih besar cempedak yang diperam dengan menggunakan karbit daripada diperam secara tradisional.

L-asam askorbat atau Vitamin C adalah antioksidan yang larut dalam air.
Bentuk dari Vitamin C adalah kristal putih dengan rumus molekul $\mathrm{C} 6 \mathrm{H} 8 \mathrm{O} 6$ dan berat molekul 176.13 yang secara reversible mudah teroksidasi dengan kehilangan 2 atom hydrogen dan membentuk asam dehidro L-asam askorbat (Sibagariang. 2010). Vitamin $C$ dalam keadaan kering dan stabil tetapi jika vitamin $\mathrm{C}$, terutama jika terdapat di udara, cahaya, logam-logam seperti $\mathrm{Cu}$, Fe dan berada dalam bentuk larutan akan terdegradasi atau mudah rusak. Vitamin C mempunyai sifat yang paling utama adalah mudah tereduksi yang dikatalis oleh beberapa logam terutama $\mathrm{Cu}$ dan $\mathrm{Ag}$ kemudian memiliki kemampuan mereduksi yang kuat (Sediaoetomo, 2007).

Kadar kandungan vitamin C memiliki perbedaan anatara pemeraman dengan menggunakan karbit lebih besar jika dibandingkan kandungan vitamin c pada 
Agroradix Vol. 3 No.1 Desember (2019)

ISSN : 2621-0665

cempedak yang diperam secara tradisional. Karbit atau kalsium secara khusus dapat menhasilkan panas dan berfungsi sama seperti etilen. 1 gram $\mathrm{CaC} 2$ menghasilkan $349 \mathrm{ml}$ asetilen. Dengan demikian proses pematangan buah akan menjadi lebih cepat jika dibanding pematangan buah secara biasa. Pemeraman buah akan lebih cepat mencapai stadium klimaterik, namun muhajir (Prabawati et al, 2008) berpendapat bahwa terlalu tingginya suhu dapat mengakibatkan terjadinya kelainan fisiologis. $\mathrm{Hal}$ tersebut selaras dengan penelitian yang dilakukan sri utami (Sri utami 2011) menyatakan bahwa pada pisang buah raja yang diperam dengan memakai karbit memiliki kadar kandungan vitamin c tertinggi yaitu sebesar $7,85 \mathrm{mg} / 100 \mathrm{mg}$ jika dibandingkan dengan pisang raja yang diperam dengan menggunakan daun memiliki kandungan vitamin $\mathrm{c}$ sebesar 7,78mg/100 $\mathrm{mg}$, dan pemeraman tanpa bahan $(7,81 \mathrm{mg} / 100 \mathrm{mg})$. Kadar kandungan vitamin c pada buah masa karbit yang digunakan mempengaruhi terhadap kadar vitamin c. masa kadar karbit yang digunakan semakin tinggi maka kadar vitamin c yang dihasilkan buah semakin tinggi. peningkatan konsentrasi zat perangsang buah akan meningkatkan kadar vitamin c (Rhidiyanti, S. P. 2015).

Pemeraman secara tradisional pada dasarnya membutuhkan waktu yang lebih lama jika dibandingkan pemeraman dengan menggunakan karbit. Kecepatan buah dalam mengalami fase klimaterik ini sangat memiliki pengaruh terhadap kandungan vitamin c. pada buah yang matang lebih cepat karena penyimpanan yang cenderung lebih cepat. Apabila waktu penyimpanan buah lebih lama dapat menurunkan kandungan vitamin c. Hal ini selaras dengan penelitian yang dilaksanakan oleh Zahroh (Farikhah Asiati zahroh, 2008) bahwa pisang kepok kuning mengalami penurunan kandungan vitamin c seiring dengan lamanya waktu yang dibutuhkan dalam proses pematangan. Penurunan kandungan vitamin C disebabkan karena sifat vitamin c yang mudah larut dalam air dan mempunyai sifat asam serta mudah teroksidasi.

\section{SIMPULAN}

Berdasarkan penelitian yang telah dilakukan maka didapatkan total rata-rata kandungan vitamin c selai cempedak yang diperam dengan karbit adalah 15.67 mg/100 mg sedangkan yang diperam rata-rata kandungan vitamin c $12.07 \mathrm{mg} / 100 \mathrm{mg}$. Nilai sginifikansi dengan menggunakan ANAVA sebesar 0,026 lebih kecil dari 0,05 yang berarti bahwa terdapat perbedaan yang nyata pada kandungan vitamin $\mathrm{c}$ selai cempedak antara cempedak yang diperam secara tradisional dengan cempedak yang diperam dengan menggunakan karbit.

\section{DAFTAR PUSTAKA}

Abdullah Bin Arif, Wahyu Diyono, Enrico Syaefullah, Suyanti dan Setyadjit. 2014. Optimalisasi Cara Pemeraman Buah Cempedak (Artocarpus champeden). Informatika pertanian vol 23 no $135-46$

Andreas pandiangan, Faizah Hamzah dan Rahmayuni. 2017. pembuatan selai campuran buah pepaya dan buah terung belanda. Jom fakultas pertanian, volume 4 no 2. Riau

Anindia Putri Hardita, Ni Made Yusa, Agus Slamet Duniaji. 2016. pengaruh rasio 
Agroradix Vol. 3 No.1 Desember (2019)

ISSN : 2621-0665

daging dan kulit buah naga merah (hylocereus polyrhizus) terhadap karakteristik selai. universitas udayana jurnal ilmu teknologi dan pangan vol 5 no 1 issn 2527-8010. Bali

Arif, Diyono W, Syaefullah E, Suyanti dan Setyadjit. 2014. Optimalisasi cara pemeraman buah cempedak

Astawan, Prof. Dr. Made. 2009. Cempedak. Sahabat Mata.

Dahlan, Dwi Nur Aini, 2018, the influence of cempedak (artocarpus champedan lour.) Ripening Variation On Organoleptic Properties Of Jam Produced. International Journal of Current Research In Biosciences And Plant Biology vol 5 no 6 issn: 23498080

Farikhah Asiati zahroh, 2008, pengaruh penggunaan daun albasia (Albazzia falcata) dan lama pemeraman pisang kepok terhadap kandungan vitamin C. skripsi. Yogyakarta fakultas sains dan teknologi Universitas Islam Negeri Kalijaga.

Fitmawati, Via andani, Nery Sofiyanti. Jenisjenis cempedak (Artocarpus champaden Lour.) di kabupaten kampar provinsi Raiau. Riau. Ekotonia: Jurnal Penelitian Botani, Zoologi dan mikrobiologi, Volume 04 nomor 1 juni 2018

Kaleka, N. 2013. Commercial Bananas. Arcita Publisher. Surakarta. first edition

Leong L. P dan G. Shui. 2002. An Investigation of Antioxsidant Capacity of Fruit in Singapore Markets. Food Chemistry. 76: 69-75
Lim TK, 2012, Edible Medicinal and NonMedicinal Plants 3. Fruits. Springer sciece business media B.V. New York. Pp: 337-343

Mia Aina dan Dawam Suprayogi. 2011. Uji Kualitatif Vitamin C Pada Berbagai Makanan Dan Pengaruhnya Terhadap Pemanasan. Jambi. Sainmatika: Jurnal Sains dan Matematika Universitas, Volume 3, No. 1. 61-67.

Perricone, N. 2007. The Perricone Prescription. Jakarta: Serambi IImu Semesta

Prabawati, S., Suyanti dan Setyabudi, D.A. 2008. Teknologi Pascapanen dan Pengolahan Buah Pisang. Balai Besar Penelitian dan Pengembangan Pascapanen Pertanian. Dalam seminar Badan Litbang Pertanian. Departemen Pertanian, Bogor.

Rhidiyanti, S. P, Elisa, J. dan Linda.M.L. 2015. Pengaruh pemberian ethhepon sebagai zat perangsang pematangan terhadap mutu buah pisang barangan (Musa paradisiaca L). jurnal rekayasa pangan dan pertanian. Vol 3 no 1. 1-13

Sibagariang, E, E,.., Pusmaika, Rismalinda, 2010, Kesehatan Reproduksi Wanita. Jakarta: Trans Info Media.

Singal, S., M.Kumud dan S.Thakral, 2012. Application of apple as ripening agent for banana. Indian J.of Natural Products and Resources 3 (1): 61-64.

Sri utami, joko widiyanto dan kristianita. 2013. pengaruh dan cara lama pemereman terhadap kandungan vitamin C pada buah pisang raja 
Agroradix Vol. 3 No.1 Desember (2019)

ISSN : 2621-0665

(Musa paradisiaca L). jurnal edukasi matematika dan sains vol 1 no 2

Sri utami, joko widiyanto dan kristianita.

Pengaruh dan cara lama pemeraman terhadap kandungan vitamin c pada buah pisang raja (Musa paradisiaca L.). jurnal edukasi matematika dan sains vol 1 no 2

Tetty, NAH. 2011. Pengaruh perbandingan konsentrasi sukrosa dan sari buah cempedak (artocarpus integer (tunb) Merr) terhadap kualitas permen jelly selama masa simpan. Skripsi. Yogyakarta: fakultas terknologi program studi biologi universitas atmajaya ypgyakarta.

Verheij, E.W.M dan R.E. Coronel. 1997. Sumber Daya Nabati Asia Tenggara 2: Buah-buahan yang dapat dimakan. Jakarta: PT. Gramedia Pustaka Utama 